\title{
PENGARUH IKLIM TERHADAP KEJADIAN DEMAM BERDARAH DENGUE DI KOTA TERNATE
}

\author{
M. Rasyid Ridha ${ }^{{ }^{*}}$, Liestiana Indriyati ${ }^{1}$, Amalan Tomia $^{2}$, Juhairiyah ${ }^{1}$ \\ ${ }^{1}$ Balai Penelitian dan Pengembangan Tanah Bumbu, \\ Jl. Loka Litbang Kawasan Perkantoran Pemda Tanah Bumbu, Kelurahan Gunung Tinggi, Kecamatan \\ Batulicin, Pondok Butun, Tanah Bumbu, Pd. Butun, Batu Licin, Kabupaten Tanah Bumbu, Kalimantan \\ Selatan 72271, Indonesia \\ 2Universitas Muhamadiyah Maluku Utara, \\ Jalan Mononutu No. 10 Tanah Raja, Maliaro, Ternate Sel., Kota Ternate, Maluku Utara 97716, Indonesia
}

\begin{abstract}
Climate change can affect to the pattern of infectious diseases and will increase the risk of the transmission, especially dengue hemorrhagic fever (DHF). The study of climate change especially temperature, humidity and rainfall is needed for early warning of increasing DHF cases. The data source uses research data "DHF events based on climate factors in Ternate" Analysis with path analysis to explain the mechanism of the casual relationship between rainfall, air humidity, air temperature and the incidence of DHF cases. DHF cases in Ternate were found relatively higher in the wet month, especially in the range of rainfall $>200-412 \mathrm{~mm}$, temperature $23-27^{\circ} \mathrm{C}$ and humidity $67-82 \mathrm{mmHg}$. Temperature and humidity were significantly affected in DHF cases in Ternate ( $p$ value $<0.005$ ), while rainfall even though $p$ value was not proven to be significantly influential in DHF cases, but based on rainfall path diagram have positive effect on the incidence of DHF as large as $8.4 \%$ which means that the high and low incidence of DHF is influenced by rainfall by $84 \%$. This is because rainfall directly affects the presence of dengue vector mosquito breeding sites. The cooperation between health agencies and BMKG is needed for an early warning system of dengue cases increasing by taking attention to the trend of fluctuation temperature, humidity and rainfall.
\end{abstract}

Keywords : Temperature, humidity, rainfall, DHF, early warning system

\section{THE INFLUENCE OF CLIMATE ON DENGUE HEMORRHAGIC FEVER IN TERNATE CITY}

\begin{abstract}
Abstrak
Perubahan iklim dapat berpengaruh terhadap peningkatan risiko penularan khususnya penyakit demam berdarah dengue (DBD). Kajian mengenai perubahan iklim khususnya suhu, kelembaban, dan curah hujan diperlukan guna kewaspadaan dini peningkatan kasus DBD. Sumber data menggunakan data penelitian "Kejadian DBD berdasarkan faktor iklim di Kota Ternate". Analisis menggunaan analisis jalur untuk menjelaskan mekanisme hubungan kausal antara curah hujan, kelembaban udara, suhu udara terhadap kejadian penyakit DBD. Kasus DBD di Kota Ternate ditemukan relatif lebih tinggi pada bulan basah yaitu kisaran curah hujan > 200-412 mm, suhu $23-27^{\circ} \mathrm{C}$ dan kelembaban $67-82 \mathrm{mmHg}$. Suhu dan kelembaban dinyatakan berpengaruh secara signifikan pada kasus DBD di Kota Ternate ( $p$ value $<0,005)$. Curah hujan meskipun tidak terbukti berpengaruh pada kasus DBD, akan tetapi berdasarkan diagram jalur, curah hujan berpengaruh positif terhadap kejadian penyakit DBD sebesar $8,4 \%$ yang berarti bahwa tinggi rendahnya kejadian DBD dipengaruhi oleh curah hujan sebesar $84 \%$. Hal ini disebabkan karena curah hujan berpengaruh langsung terhadap keberadaan tempat perkembangbiakan nyamuk vektor DBD. Diperlukan kerjasama antara instansi kesehatan dengan BMKG guna sistem kewaspadaan dini peningkatan kasus DBD dengan memperhatikan tren fluktuasis suhu, kelembaban, dan curah hujan.
\end{abstract}


Kata Kunci: Suhu, kelembaban, curah hujan, peringatan dini, DBD

Naskah masuk: 12 Juli 2019; Review: 30 Agustus 2019; Layak Terbit: 1 Desember 2019

*Alamat korespondensi penulis pertama: e-mail: ridho.litbang@gmail.com; Telp: (0518) 6076049

\section{PENDAHULUAN}

$\begin{array}{llrr}\text { Demam berdarah dengue } & \text { (DBD) } \\ \text { merupakan penyakit infeksi } & \text { yang } \\ \text { disebabkan oleh virus dengue dan } & \text { dan } \\ \text { ditularkan melalui nyamuk Aedes aegypti } \\ \text { dan Ae. albopictus. Virus dengue } \\ \text { merupakan genus Flavivirus, famili }\end{array}$
Flaviviridae dan mempunyai 4 jenis serotipe, yaitu: Den-1, Den-2, Den-3, dan Den-4. ${ }^{1}$ Keempat serotipe virus dengue ini telah ditemukan di berbagai wilayah di Indonesia. Banyak wilayah di Indonesia yang merupakan wilayah endemik DBD di mana kasus DBD yang berulang-ulang setiap tahun. Serangga yang diketahui menjadi vektor utama adalah nyamuk Aedes aegypti (Linn.) dan nyamuk kebun Aedes albopictus (Skuse.)(Diptera: Culicidae). Kedua spesies nyamuk itu ditemukan di seluruh wilayah Indonesia kecuali pada ketinggian di atas 1000 meter di atas permukaan laut (mdpl), ${ }^{2,3}$ sedangkan di daerah lain seperti Kota Meksiko bisa mencapai 2130 mdpl. ${ }^{4}$

Nyamuk Ae. aegypti dan Ae. albopictus adalah nyamuk tropis yang berasal dari Afrika Tengah dan biasanya ditemukan pada habitat yang berbeda. Ae. aegypti lebih menyukai daerah perkotaan dan domestik, yaitu di sekitar tempat tinggal manusia dan cenderung berkembang biak di kontainer buatan, sedangkan Ae. albopictus banyak ditemukan pada daerah pedesaan dan lebih banyak berkembang di habitat alami, tetapi ditemukan pula pada tempat penampungan air. ${ }^{5}$

Menurut data WHO (2014) penyakit demam berdarah dengue pertama kali dilaporkan di Asia Tenggara pada tahun 1954 yaitu di Filipina, selanjutnya menyebar ke berbagai negara. Sebelum tahun 1970, hanya 9 negara yang mengalami wabah
DBD, tetapi sekarang DBD menjadi penyakit endemik pada lebih dari 100 negara, diantaranya adalah Afrika, Amerika, Mediterania Timur, Asia Tenggara dan Pasifik Barat memiliki angka tertinggi terjadinya kasus DBD. ${ }^{6}$ Jumlah kasus di Amerika, Asia Tenggara, dan Pasifik Barat telah melewati 1,2 juta kasus pada tahun 2008 dan lebih dari 2,3 juta kasus pada tahun 2010. Pada tahun 2013 dilaporkan terdapat sebanyak 2,35 juta kasus di Amerika dan 37.687 kasusnya merupakan DBD berat. Perkembangan kasus DBD di tingkat global semakin meningkat, seperti dilaporkan Organisasi Kesehatan Dunia (WHO) yakni dari 980 kasus di hampir 100 negara tahun 1954-1959 menjadi 1.016.612 kasus di hampir 60 negara tahun 20002009. . $^{7,6}$

Dinas Kesehatan Kota Ternate tahun 2013 melaporkan bahwa terjadi penurunan kejadian DBD dari tahun 2010-2012, yaitu dari 210 kasus DBD dan 8 kasus kematian (Case Fatality Rate 3,9\%) pada tahun 2010 menjadi 57 kasus DBD dan 3 kasus kematian (CFR 5,3\%) pada tahun 2011 dan pada tahun 2012 kasus DBD menjadi 32 kasus dengan tidak ada kasus kematian. Walaupun dari tahun 2010-2012 terjadi penurunan jumlah kasus, tetapi perlu pengawasan terhadap lingkungan, karena Angka Bebas Jentik (ABJ) masih di bawah target, yaitu $71,8 \%$. Penyebaran kasus DBD di Pulau Ternate sudah menjangkau seluruh kecamatan. Tahun 2011 penyebaran DBD di Kota Ternate dikelompokkan menjadi tiga kategori, yaitu 36 kelurahan termasuk daerah endemis, 17 kelurahan termasuk daerah sporadis, dan 6 kelurahan termasuk daerah potensial. Pada tahun 2014 wilayah yang dikategorikan sebagai daerah endemis sebanyak 4 
kelurahan, sporadis sebanyak 16 kelurahan, dan daerah potensial 43 kelurahan. $^{8}$

Perubahan iklim dapat berpengaruh terhadap pola penyakit infeksi dan akan meningkatkan risiko penularan. ${ }^{9}$ Hal yang berpengaruh tersebut adalah suhu, kelembaban, dan curah hujan. ${ }^{10}$ Suhu ideal untuk transmisi DBD adalah 21.6-32.9 ${ }^{\circ} \mathrm{C}$ dengan kelembaban berkisar $79 \% .^{11}$ Perubahan iklim juga menyebabkan beberapa virus diperkirakan mengalami peningkatan pada peralihan musim yang ditandai oleh curah hujan dan suhu udara yang tinggi. ${ }^{1}$

Kondisi terjadinya penyakit DBD yang selalu terjadi setiap tahunnya di Kota Ternate serta masih minimnya kajian mengenai pengaruh perubahan iklim (curah hujan, kelembaban udara, dan suhu udara) di wilayah Ternate, mendorong perlu dilakukan penelitian lebih seksama mengenai hal yang terkait dengan pengaruh iklim terhadap kejadian DBD yang bermuara kepada pencegahan kasus DBD melalui upaya kewaspadaan dini. Prediksi kejadian DBD dimasa yang akan datang dapat meningkatkan kewaspadaan terhadap kejadian dan pola penyakit. Tujuan penelitian ini yaitu untuk menganalisis besar pengaruh curah hujan, suhu, dan kelembaban udara terhadap kejadian penyakit DBD di Kota Ternate tahun 20072014.

\section{METODE}

Sumber data yang digunakan adalah data penelitian "Kejadian DBD berdasarkan faktor iklim di Kota Ternate". Variabel yang diteliti dalam penelitian ini meliputi variabel bebas (data iklim meliputi curah hujan, kelembaban, dan suhu udara) dan variabel terikat yakni data jumlah kasus penyakit DBD yang dilaporkan oleh puskesmas dan rumah sakit ke Dinas Kesehatan Kota Ternate dalam periode tahun pelaporan 2007-2014.

Pengumpulan data yang dilakukan saat penelitian "Kejadian DBD berdasarkan faktor iklim di Kota Ternate" yaitu observasi dokumen dari laporan yang ada di Dinas
Kesehatan Kota Ternate, Badan Meteorologi Klimatologi dan Geofisika (BMKG) Klas III Stasiun Klimatologi Ternate dan Badan Meteorologi Klimatologi dan Geofisika (BMKG) Klas II Stasiun Klimatologi Bandara Babullah Ternate. Analisis untuk menjelaskan mekanisme hubungan kausal antara curah hujan, kelembaban udara, suhu udara terhadap kejadian penyakit DBD dilakukan analisis jalur (path analysis).

Tahapan yang dilakukan dalam analisis jalur adalah melakukan pemeriksaan asumsi kenormalan data secara multivariat, uji kelayakan model, dan dengan tabel dekomposisi serta diagram jalur hasil uji kemaknaan koefisien jalur. Model struktural yang dihasilkan sebagai berikut:

$$
\begin{aligned}
X 2= & p X 2 X 1 X 1+e X 2 \text { (substruktural } 1) \\
X 3= & p X 3 X 1 \times 1+p X 3 X 2 \times 2+e X 3 \\
& (\text { substruktural } 2) \\
Y 1= & p Y 1 X 1 X 1+p Y 1 X 2 X 2+p Y 1 X 3 X 3+ \\
& p Y 1 \text { (substruktural 3) }
\end{aligned}
$$

Analisis jalur atau yang lebih dikenal luas sebagai path analysis merupakan suatu metode pendekomposisian atau perubahan menjadi bentuk yang lebih sederhana dari korelasi kedalam bagianbagian yang berbeda untuk menginterpretasikan suatu pengaruh (effect). ${ }^{12}$ Dalam analisis jalur yang distandarkan korelasi dapat dipecah kedalam komponen-komponen struktural (kausal) dan nonstruktural (nonkausal) didasarkan teori yang dinyatakan dalam diagram jalur. ${ }^{13}$

\section{HASIL}

Kasus DBD di Kota Ternate cenderung menurun dari tahun 2007 hingga tahun 2014. Peningkatan kasus terjadi di bulan Desember hingga Juli yaitu di awal musim penghujan. Jumlah kasus DBD tertinggi berada di bulan Maret 2010 sebanyak 48 kasus. Tahun 2010 merupakan jumlah kasus tertinggi dibandingkan tahun lainnya, sedangkan terendah pada tahun 2012. (Gambar 1). 


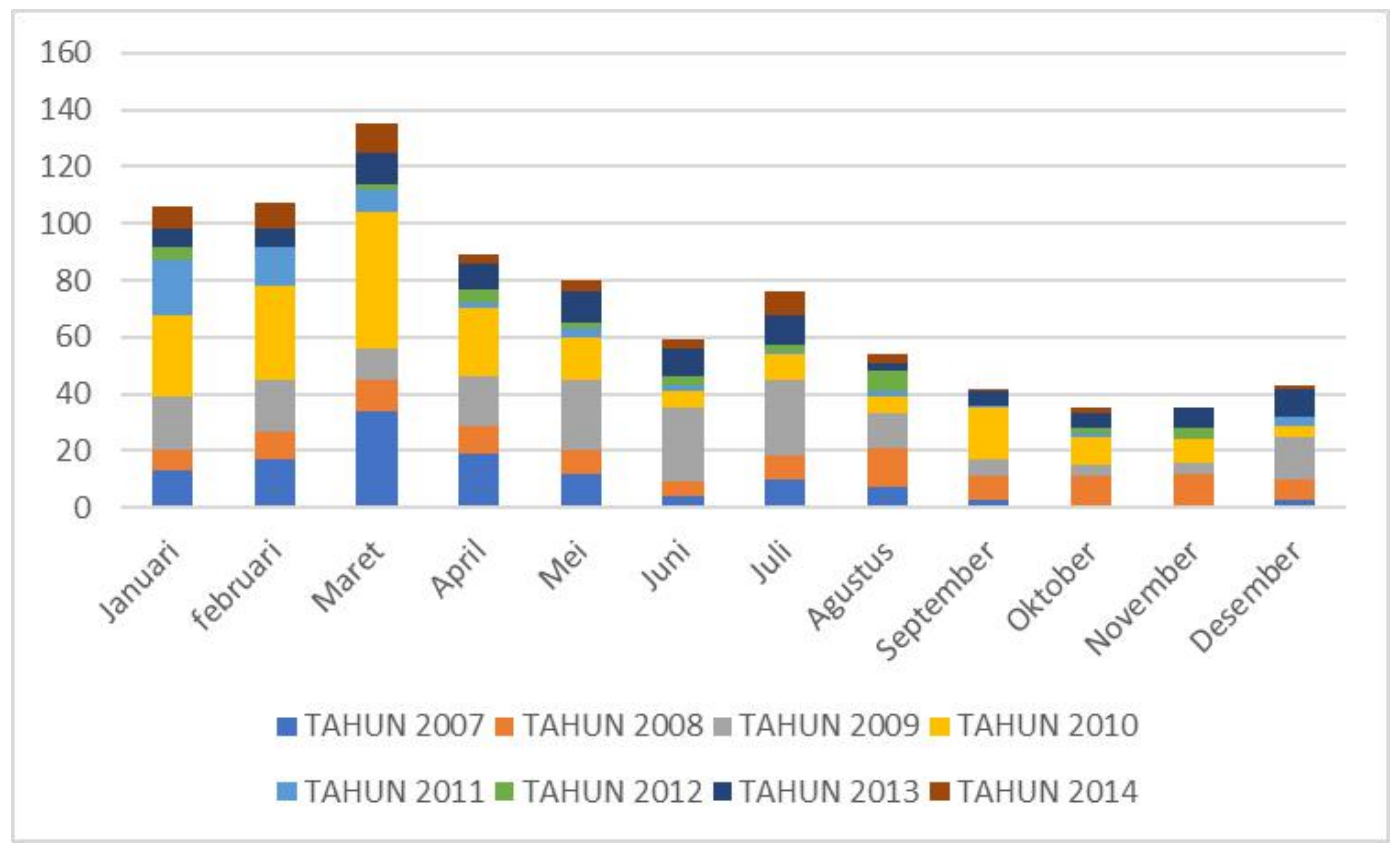

Gambar 1. Jumlah Kasus DBD tahun 2007 - 2014 di Kota Ternate

Jumlah curah hujan cenderung meningkat pada bulan November hingga Maret setiap tahunnya. Curah hujan ratarata tertinggi berada pada bulan November 2007 (Gambar 1). Kelembaban udara cenderung berada pada kisaran $60-70 \%$ setiap tahunnya, sedangkan yang tertinggi pada bulan Agustus 2009 yaitu sebesar $79 \%$, sedangkan suhu udara berada pada kisaran $22-27^{\circ} \mathrm{C}$ (Gambar 2).
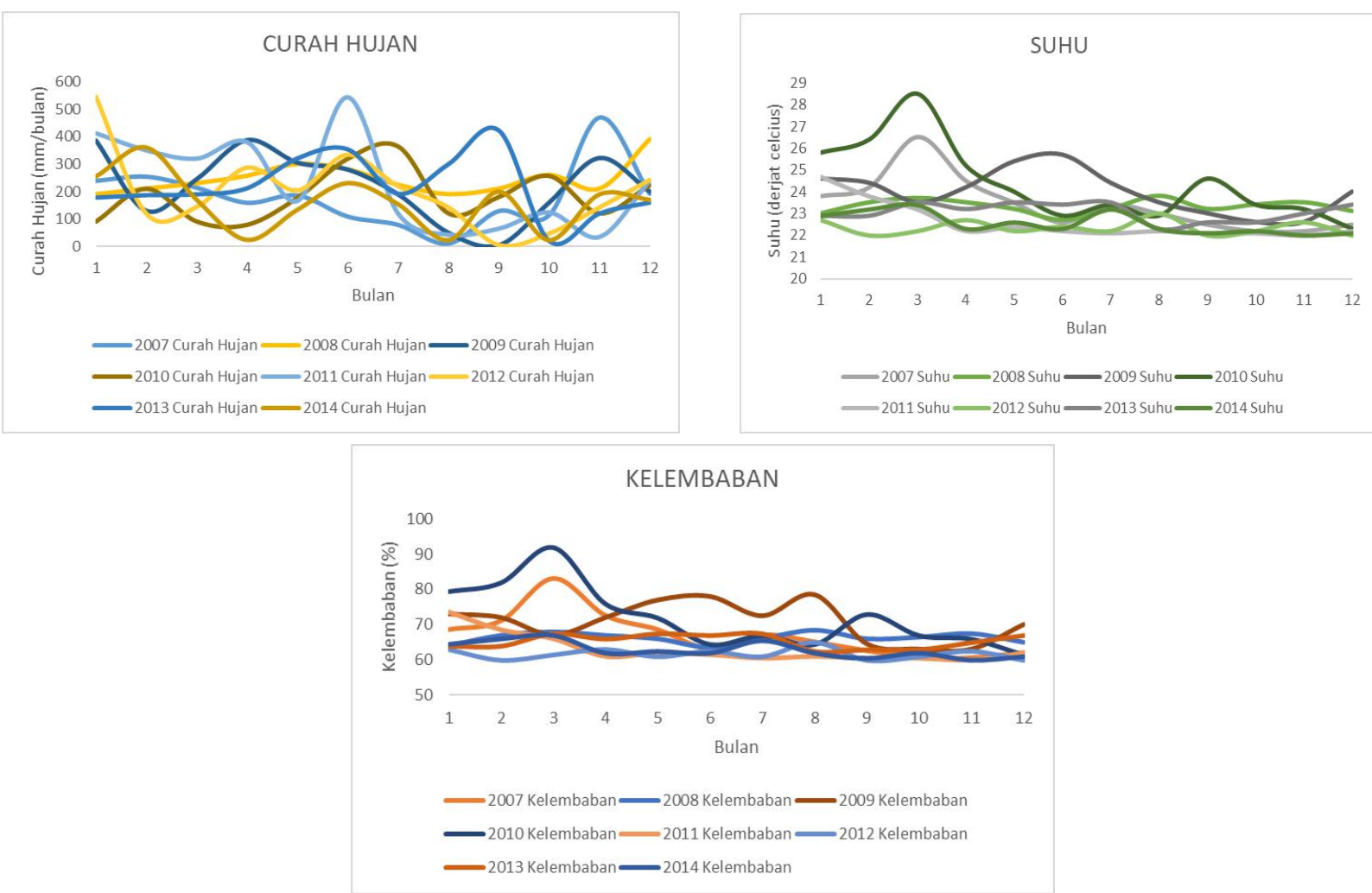

Gambar 2. Grafik Suhu, Curah Hujan, dan Kelembaban di Kota ternate tahun $2007-2014$ 
Selanjutnya, untuk mengetahui besar pengaruh antara perubahan iklim yang meliputi curah hujan, kelembaban, suhu dengan kejadian penyakit DBD, dilakukanlah analisis jalur (path analysis). Analisis jalur ini digunakan untuk menjelaskan mekanisme hubungan kausal antara curah hujan $\left(\mathrm{X}_{1}\right)$, kelembaban $\left(\mathrm{X}_{2}\right)$, suhu $\left(X_{3}\right)$, terhadap kejadian penyakit DBD $\left(\mathrm{Y}_{1}\right)$. Analisis jalur pengaruh curah hujan, kelembaban, suhu terhadap kejadian penyakit DBD ditunjukkan pada tabel 2,3 dan 4.

Tabel 2. Koefesien jalur pengaruh kelembaban dan suhu terhadap curah hujan di Kota Ternate

\begin{tabular}{|c|c|c|c|c|c|}
\hline & \multirow[t]{2}{*}{ Model } & \multicolumn{2}{|c|}{ Unstandardized Coefficients } & \multirow{2}{*}{$\begin{array}{c}\text { Standardized } \\
\text { Coefficients }\end{array}$} & \multirow[t]{2}{*}{$p$} \\
\hline & & $B$ & Std. Error & & \\
\hline \multirow[t]{3}{*}{1} & (Constant) & 89.453 & 138.823 & & .521 \\
\hline & Suhu & -.085 & .389 & -.027 & .828 \\
\hline & Kelembaban & 1.782 & 2.021 & .108 & .380 \\
\hline \multirow[t]{4}{*}{2} & (Constant) & -84.344 & 2.676 & & .000 \\
\hline & $\begin{array}{l}\text { Curah_Hujan } \\
\text { (X1) }\end{array}$ & .000 & .002 & .007 & .805 \\
\hline & Suhu (X2) & .193 & .007 & .834 & .000 \\
\hline & $\begin{array}{l}\text { Kelembaban } \\
\text { (X3) }\end{array}$ & 1.345 & .039 & 1.121 & .000 \\
\hline
\end{tabular}

Pada Tabel 2 dapat diketahui bahwa hanya variabel kelembaban $\left(X_{1}\right)$ yang memiliki nilai positif untuk unstandardized coefficients ( $B$ value $=1,782$ ) dimana hal tersebut dimaknai sebagai pengaruh yang positif terhadap variabel curah hujan $\left(\mathrm{X}_{3}\right)$. Dari nilai standar koefisien Beta diperoleh interpretasi bahwa setiap peningkatan sebesar 1 satuan variabel kelembaban akan meningkatkan variabel curah hujan sebesar 0,108 satuan dengan asumsi variabel bebas lain dianggap konstan.

Pada Tabel 2 (nomor 2) terlihat bahwa variabel kelembaban $\left(X_{1}\right)$, suhu $\left(X_{2}\right)$, dan curah hujan $\left(X_{3}\right)$ memiliki nilai positif untuk unstandardized coefficients (B) dimana hal tersebut dimaknai sebagai pengaruh yang positif terhadap variabel kejadian penyakit DBD $\left(Y_{1}\right)$. Dari nilai standar koefisien Beta diperoleh interpretasi bahwa setiap peningkatan sebesar 1 satuan variabel kelembaban akan meningkatkan variabel kejadian penyakit DBD sebesar 1,121 satuan. Begitupun pada variabel curah hujan dapat diintrepetasikan bahwa setiap peningkatan sebesar 1 satuan variabel curah hujan akan meningkatkan variabel kejadian penyakit DBD sebesar 0,07 satuan dan peningkatan sebesar 1 satuan variabel suhu akan meningkatkan variabel kejadian penyakit DBD sebesar 0,843 dengan asumsi variabel bebas lain dianggap konstan.

Tabel 4. Hasil estimasi parameter model

\begin{tabular}{lrrrrr}
\hline \multicolumn{1}{c}{ Model } & Kofesien Jalur & \multicolumn{1}{c}{$\mathrm{T}$} & $\mathrm{p}$ & $\mathrm{R}$ & $\mathrm{R}$ \\
\hline Sub struktural 1 (X1 X1 ke X3 & & & & & \\
X1 Kelembaban & -.027 & -.218 & .828 & 0,16 & 0,84 \\
X2 Suhu & .108 & .882 & .380 & & \\
\hline Sub struktural 1 (X1 X1 X3 ke Y1) & & & & & \\
X1 Kelembaban & .007 & .247 & .000 & .932 & 0,068 \\
X2 Suhu & .834 & 25.746 & .000 & & \\
X3 Curah Hujan & 1.121 & 34.457 & .805 & & \\
\hline
\end{tabular}


Pada Tabel 4 terlihat bahwa secara berurutan kelembaban serta suhu berpengaruh positif dan signifikan terhadap curah hujan (X3) dengan nilai $p$ value = 0.0000 ( $p$ value $<0.05$ ). Besaran pengaruh simultan (R2) adalah 0,932 atau dibulatkan menjadi 93\% merupakan kontribusi dari variabel kelembaban terhadap curah hujan, sedangkan sisanya $7 \%$ dipengaruhi faktor lain di luar model ini. Secara parsial kelembaban relatif berpengaruh positif dan signifikan terhadap curah hujan. Cuaca dipengaruhi dengan beberapa faktor yaitu suhu, kelembaban relatif, tekanan udara, kecepatan angin, total lapisan awan, dan penyinaran matahari, sedangkan cuaca adalah keadaan atmosfer pada saat yang pendek dan di tempat tertentu. Keadaan atmosfer itu merupakan gabungan dari bebagai unsur, antara lain suhu udara, tekanan udara, angin, kelembaban udara, dan presipitasi. Besaran langsung kelembaban relatif terhadap curah hujan adalah $0,007(0,7 \%)$, artinya tinggi rendahnya curah hujan dipengaruhi oleh kelembaban relatif sebesar 93\%, sedangkan sisanya dipengaruhi oleh faktor lain di luar model.

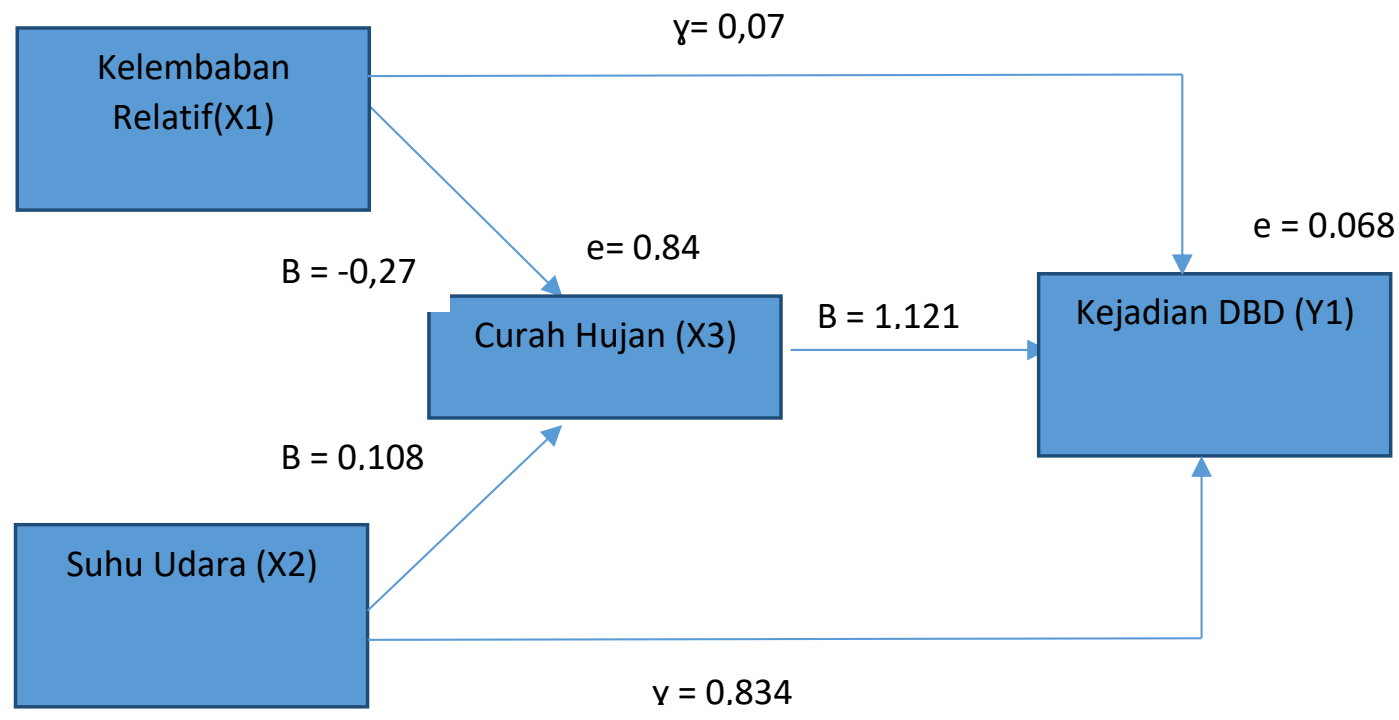

Gambar 2. Diagram jalur hubungan variabel kelembaban (X1), suhu (X2) dan curah hujan (X3) terhadap Kejadian DBD ( $\left.\mathrm{Y}_{1}\right)$

Secara keseluruhan, pengaruh yang dibentuk dari variabel iklim digambarkan pada diagram jalur pada Gambar 2, curah hujan dipengaruhi oleh kelembaban dan suhu udara. Pengaruh tidak langsung X1 ke Y1 melalui

$$
\text { X3 }=-0,27 \times 0,84=-0,2268 .
$$

Dengan demikian pengaruh totalnya $=$

$$
0,07+-0,2268=-0,1568 \text {. }
$$

Pengaruh tidak langsung $\mathrm{X} 2$ ke $\mathrm{Y} 1$ melalui

$$
\mathrm{X} 3=0,108 \times 0,84=0,090 .
$$

Dengan demikian pengaruh totalnya = $0,834+0,090=0,925$.

Berdasarkan diagram jalur, curah hujan berpengaruh positif terhadap kejadian penyakit DBD sebesar $8,4 \%$. Hal ini berarti tinggi rendahnya kejadian DBD dipengaruhi oleh curah hujan sebesar $84 \%$, sedangkan faktor lain di luar model ini dapat mempengaruhi kejadian DBD sebesar $16 \%$.

\section{BAHASAN}

Hasil penelitian menyatakan bahwa suhu dan kelembaban relatif memiliki pengaruh yang bermakna terhadap kasus DBD di Kota Ternate sementara curah hujan tidak terbukti berpengaruh terhadap kasus DBD. Hasil analisis ini berbeda dengan hasil penelitian Wirayoga di Kota Semarang yang menyatakan bahwa suhu udara, curah hujan, dan kelembaban relatif mempunyai hubungan yang bermakna terhadap kejadian demam berdarah 
Kelembaban berpengaruh terhadap

dengue. ${ }^{14}$ Hasil penelitian Zubaidah juga menyatakan sebaliknya bahwa curah hujan memiliki pengaruh yang paling dominan terhadap kejadian penyakit DBD di Kota Banjarbaru, sementara itu faktor kelembaban relatif berpengaruh secara tidak langsung kepada peningkatan kejadian DBD melalui mekanisme peningkatan curah hujan. ${ }^{15}$ Penelitian lainnya justru menyatakan bahwa kelembaban relatif tidak ditemukan sebagai prediktor kuat $^{16}$ dan diperkuat juga oleh studi sebelumnya yang telah menunjukkan kelembaban relatif bukan variabel yang signifikan dalam distribusi spasial atau temporal demam berdarah di Indonesia. ${ }^{17}$ Perbedaan tersebut disebabkan oleh mekanisme adaptasi vektor DBD bersifat lokal spesifik terhadap karakteristik suhu, kelembaban relative, dan curah hujan pada masing-masing daerah.

Kasus DBD di Kota Ternate relatif lebih tinggi pada kisaran suhu $23-27^{\circ} \mathrm{C}$ dan kelembaban $67-82 \%$, sementara curah hujan sebagian besar pada kisaran 190-412 $\mathrm{mm}$. Suhu dan kelembaban mempengaruhi biologi vektor dan interaksi vektor-virus, umur dan ketahanan vektor, perkawinan, penyebaran, perilaku makan dan oviposisi, serta replikasi virus yang lebih cepat. ${ }^{18}$ Sebagai hewan berdarah dingin maka proses-proses metabolisme dan siklus kehidupan nyamuk tergantung pada suhu lingkungan di sekitarnya. Suhu rata-rata optimum untuk perkembangan nyamuk yaitu $25-30^{\circ} \mathrm{C}$, sedangkan aktivitas nyamuk tertinggi atau paling aktif yaitu pada suhu $29^{\circ} \mathrm{C}$ dan aktivitas terendah yaitu pada suhu $32^{\circ} \mathrm{C} .^{19}$ Pernyataan tersebut sesuai dengan hasil penelitian ini yaitu kasus DBD tertinggi di Kota Ternate sebanyak 48 kasus terjadi pada suhu $29^{\circ} \mathrm{C}$ yaitu pada bulan Maret 2010. Menurut Rohimat, 2002 dalam Ariati, 2012 saat pergantian musim penghujan ke musim kemarau kondisi suhu udara berkisar antara $23-31^{\circ} \mathrm{C}$, hal ini merupakan kisaran suhu yang optimum untuk perkembangbiakan nyamuk (24$\left.28^{\circ} \mathrm{C}\right) \cdot{ }^{20}$ umur nyamuk, tingkat kelembaban $60 \%$ merupakan batas paling rendah untuk memungkinkan nyamuk hidup. Pada kelembaban kurang dari $60 \%$ umur nyamuk akan menjadi pendek dan tidak bisa menjadi vektor karena tidak cukup waktu untuk perpindahan virus dari lambung ke kelenjar ludah. Kasus DBD tertinggi di Kota Ternate terjadi pada kelembaban $92 \%$ yaitu pada bulan Maret 2010. Hal ini agak bertentangan dengan hasil penelitian lainnya yang menyatakan bahwa kelembaban optimum bagi kehidupan nyamuk adalah $70 \%-90 \% .^{20}$

Selain berpengaruh pada keberadaan dan aktivitas vektor, suhu dan kelembaban pada kasus DBD juga berpengaruh pada angka infeksi trans-ovari (AIT) virus dengue pada nyamuk Ae. aegypti. Transmisi transovari virus dengue turut memberikan kontribusi untuk terpeliharanya virus DBD di suatu daerah endemis karena nyamuk yang terinfeksi secara trans-ovari mempunyai kemampuan menularkan virus dengue secara oral melalui kelenjar ludah kepada individu yang sehat tanpa adanya kontak antara nyamuk vektor dengan penderita viremia sebelumnya. Hasil penelitian Pramestuti et al, AIT terdeteksi pada nyamuk Ae. aegypti dan Ae. albopictus paling tinggi di daerah Kutabanjarnegara dengan suhu rata-rata $28,3^{\circ} \mathrm{C}$ dan kelembaban $71,3 \% .{ }^{21}$ Hasil penelitian Joshi et al (1996) di India mendeteksi transmisi trans-ovari virus Dengue serotipe DEN-3 pada nyamuk $A e$. aegypti pada suhu ratarata $13-33^{\circ} \mathrm{C}^{22}$ sementara penelitian lain oleh Akbar, et al (2008) di Bandung menemukan transmisi trans-ovari virus dengue serotipe DEN-2 pada nyamuk $A e$. aegypti dengan suhu rata-rata $32,3^{\circ} \mathrm{C}$ dan kelembaban udara $66 \% .^{22}$ Penelitian Suardipa, 2010 dalam Pramestuti juga menyatakan bahwa angka infeksi transovari (AIT) virus DEN-2 pada nyamuk $A e$. aegypti tertinggi pada temperatur $25,5^{\circ} \mathrm{C}$ - 
$28^{\circ} \mathrm{C}$ dan kelembaban $79-87 \%$ yaitu sebesar $61,1 \%$ dan $55,6 \% .^{21}$

Hasil penelitian Sintorini, 2007 menyatakan bahwa terdapat hubungan yang bermakna antara curah hujan dengan kasus DBD di Kota DKI Jakarta (p:0,002). ${ }^{23}$ Pada penelitian ini, meskipun curah hujan tidak berpengaruh signifikan pada kasus DBD, akan tetapi dapat dikatakan bahwa kasus DBD relatif lebih tinggi pada bulan basah berdasarkan klasifikasi Oldeman yaitu curah hujan $>200 \mathrm{~mm} \cdot{ }^{24}$ Hal ini disebabkan oleh curah hujan berpengaruh langsung terhadap keberadaan tempat perkembangbiakan nyamuk vektor DBD. Curah hujan yang tinggi dapat meningkatkan jumlah genangan air alami dan penampungan air hujan seperti wadah, botol atau kaleng bekas, dan yang lainnya yang berpotensi menjadi habitat perkembangbiakan nyamuk vektor DBD, akan tetapi curah hujan yang terlalu tinggi atau curah hujan tinggi yang berlangsung dalam waktu yang lama dapat menyebabkan banjir sehingga dapat menghilangkan tempat perkembangbiakan nyamuk $A e$. albopictus dan Ae. aegypti dan menyebabkan kelimpahan populasi nyamuk berkurang. ${ }^{18}$ Hal ini yang menyebabkan pada awal tahun 2012 di Kota Ternate tidak terjadi lonjakan kasus DBD karena curah hujan sangat tinggi pada Januari 2012 yaitu mencapai $545 \mathrm{~mm}$. Sebaliknya jika curah hujan kecil dan dalam waktu yang lama, maka juga akan menambah tempat perkembangbiakan nyamuk dan meningkatkan populasinya. ${ }^{20}$ Menurut Sukowati dalam Ariati 2012 bahwa Indeks Curah Hujan $(\mathrm{ICH})$ tidak secara langsung berpengaruh pada proses perkembangbiakan nyamuk, akan tetapi berpengaruh terhadap curah hujan ideal. Curah hujan ideal yaitu air hujan yang tidak menimbulkan banjir dan air menggenang di suatu wadah/media dan menjadi tempat perkembangbiakan nyamuk. ${ }^{20}$
Beberapa hasil penelitian menyatakan bahwa terdapat waktu tunda atau waktu jeda antara peningkatan curah hujan dengan peningkatan kasus DBD. Meskipun di Kota Ternate tidak selalu menunjukkan pola tersebut, akan tetapi waktu tunda atau waktu jeda tersebut dapat menjelaskan ketidaksesuaian antara puncak kelembaban $(92 \mathrm{mmHg})$ yang tidak sesuai dengan kelembaban optimum nyamuk saat berlangsungnya puncak kasus DBD di bulan Maret tahun 2010 karena kelembaban di bulan sebelumnya (82 $\mathrm{mmHg}$ ) sangat sesuai dengan kelembaban optimum ketahanan hidup nyamuk. Hasil penelitian menyatakan bahwa diperlukan waktu jeda sekitar 3 minggu untuk faktor risiko curah hujan mulai dari masuk musim hujan hingga terjadinya insiden DBD. ${ }^{23}$ Hasil penelitian Ariati menggunakan uji regresi linier menyatakan bahwa model kejadian DBD di Kota Bogor dipengaruhi oleh empat faktor iklim yaitu curah hujan, hari hujan, suhu, dan kelembaban 2 bulan sebelumnya. ${ }^{25}$ Di Kota Yogyakarta, studi menunjukkan bahwa suhu tiga bulan sebelumnya dan curah hujan dua dan tiga bulan sebelumnya adalah prediktor terbaik untuk pola penularan demam berdarah. Waktu tunda ini cenderung mewakili proses biologis dalam siklus hidup vektor. ${ }^{16}$ Hasil penelitian Iriani di Kota Palembang, terdapat korelasi antara curah hujan dan peningkatan jumlah kasus DBD yang dirawat. Korelasi terjadi sejak satu bulan sebelum dan meningkat saat puncak curah hujan, kemudian menurun satu bulan sesudahnya. Lebih detail dijelaskan bahwa bulan serta tanggal curah hujan berhimpitan dengan prevalensi kasus DBD yang dirawat dan anomali bulan puncak hujan diikuti perubahan puncak prevalensi DBD. ${ }^{26}$

\section{KESIMPULAN}

Suhu dan kelembaban berpengaruh secara bermakna pada kasus DBD di Kota Ternate. Curah hujan meskipun tidak terbukti berpengaruh pada kasus DBD, akan tetapi berdasarkan diagram jalur, curah hujan berpengaruh positif terhadap kejadian penyakit DBD bahwa tinggi rendahnya kejadian DBD dipengaruhi oleh curah hujan sebesar $84 \%$. Hal ini disebabkan karena curah hujan 
berpengaruh langsung terhadap keberadaan tempat perkembangbiakan nyamuk vektor DBD, sedangkan kasus DBD di Kota Ternate relatif lebih tinggi pada bulan basah yaitu kisaran curah hujan > 200-412 mm, suhu $23-27^{\circ} \mathrm{C}$, dan kelembaban $67-82 \mathrm{mmHg}$.

\section{SARAN}

Melakukan early warning system atau peringatan dini risiko peningkatan kasus DBD berdasarkan data suhu, kelembaban dan curah hujan di masing-masing wilayah bekerjasama antara Badan Meteorology dan Klimatologi Geofisika (BMKG) dengan instansi kesehatan (dinas kesehatan atau puskesmas). Hasil peringatan dini dapat ditindaklanjuti dengan melakukan upaya PSN dengan 3M Plus serta membentuk Gerakan 1 Rumah 1 Jumantik.

\section{KONTRIBUSI PENULIS}

Kontribusi penulis pada artikel ini yaitu, kontributor utama adalah MR dengan melakukan analisis ulang data, pendahuluan dan Metode, LI membantu melakukan entry data dan pembahasan, AT membantu menyiapkan data, J membantu menyesuaikan format dan konsep perbaikan manuscript.

\section{UCAPAN TERIMAKASIH}

Penulis mengucapkan terimakasih kepada Dinas Kesehatan Kota Ternate yang memberikan data untuk dilakukan analisis, Kepala Balai Litbangkes Tanah Bumbu yang memberikan kesempatan kepada Peneliti untuk melakukan analisis dan pengolahan data. Teman-teman peneliti yang membantu entry data dan konsultasi.

\section{DAFTAR PUSTAKA}

1. Guzman MG, Harris E. Dengue. Lancet (London, 2015;385(9966):453-65.

England).

2. Wijayanti SPM, Sunaryo S, Suprihatin S, McFarlane M, Rainey SM, Dietrich I, et al. Dengue in Java, Indonesia: Relevance of Mosquito Indices as Risk Predictors. PLoS Negl Trop Dis. 2016;10(3):1-15.
3. Reiter P. Oviposition, dispersal, and survival in Aedes aegypti: implications for the efficacy of control strategies.. Vector Borne Zoonotic Dis. 2007;7(2):261-73.

4. Lozano-Fuentes S, Hayden MH, WelshRodriguez C, Ochoa-Martinez C, TapiaSantos B, Kobylinski KC, et al. The dengue virus mosquito vector Aedes aegypti at high elevation in México. Am J Trop Med Hyg. 2012;87(5):902-9.

5. Powell JR, Tabachnick WJ. History of domestication and spread of Aedes aegypti - A Review. 2013;108(October):11-7.

6. WHO. Comprehensive guidelines for prevention and control of dengue and dengue haemorrhagic fever. WHO Regional Publication SEARO. 2011. 159-168 p.

7. Messina JP, Brady OJ, Scott TW, Zou C, Pigott DM, Duda KA, et al. Global spread of dengue virus types: Mapping the 70 year history. Trends Microbiol. 2014;22(3):138-46.

8. Dinas Kesehatan KotaTernate. Laporan Kasus Demam Berdarah Dengue (DBD). Bidang P2P. 2016.

9. Ebi KL, Nealon J. Dengue in a changing climate. Environ Res. 2016;151:115-23.

10. Naish S, Dale $P$, Mackenzie JS, McBride J, Mengersen K, Tong S. Climate change and dengue: A critical and systematic review of quantitative modelling approaches. BMC Infect Dis. 2014;14(1).

11. Xiang J, Hansen $A$, Liu Q, Liu X, Tong $M X$, Sun $Y$, et al. Association between dengue fever incidence and meteorological factors in Guangzhou, China, 2005-2014. Environ Res. 2017;153:17-26.

12. Yamin $S$, Kurniawan $H$. SPSS Complete: Teknik Analisis Statistik Terlengkap dengan Software SPSS. 2010; Penerbit Salemba Jakarta.

13. Sarwono J. Teori, Prusedur dan Teknik Analisis untuk Riset Skripsi, Tesis dan Disertasi. Jakarta: Elex Media 
Komputindo; 2014.

14. Wirayoga MA. Hubungan Kejadian Demam Berdarah Dengue dengan Iklim di Kota Semarang Tahun 2006-2011. Unnes J Public Heal. 2013;2(4):1-9.

15. Tien Zubaidah, Muhammad ratodi LM. Pemanfaatan Informasi Iklim sebagai Sinyal Peringatan Dini Kasus DBD di Banjarbaru, Kalimantan Selatan. Vektora. 2016;8(2):99-106.

16. Ramadona $\mathrm{AL}$, Lazuardi L, Hii $\mathrm{YL}$, Holmner $\AA$. Prediction of Dengue Outbreaks Based on Disease Surveillance and Meteorological Data. PLoS One. 2016;31(March):1-18.

17. Arcari $P$, Tapper N, Pfueller S. Regional variability in relationships between climate and dengue/DHF in Indonesia. Singaphore J Trop Geogr. 2007;28(3):251-72.

18. S. Jeelani SS. Aedes vector population dynamics and occurrence of dengue fever in relation to climate variables in Puducherry, South India. Int J Curr Microbiol Appl ied Sci. 2013;2(12):313322.

19. Syahribulan, Biu FM, Hassan MS. Waktu Aktivitas Menghisap Darah Nyamuk Aedes aegypti dan Aedes albopictus di Desa Pa'lanassang Kelurahan Barombong Makassar Sulawesi Selatan. J Ekol Kesehat. 2012;11(4):306-14.
20. Ariati J, Anwar D. Kejadian Demam Berdarah Dengue (DBD) dan Faktor Iklim di Kota Batam, Provinsi Kepulauan Riau. J Ekol Kesehat. 2012;11(4):279-86.

21. Pramestuti N, Widiastuti D, Raharjo J. Transmisi Trans-Ovari Virus Dengue pada Nyamuk Aedes aegypti dan Aedes albopictus di Kabupaten Banjarnegara. J Ekol Kesehat. 2013;12(3):187-94.

22. Joshi V, Singhi M CR. Transovarial transmission of dengue-3 virus by Aedes aegypti. Trans R Soc Trop Med Hyg. 1996;90:643-4.

23. Sintorini MM. Pengaruh Iklim terhadap Kasus Demam Berdarah Dengue. J Kesehat Masy Nas. 2007;2(1):11-8.

24. Handayani D, Ningsih U. Metode Thiessen Polygon untuk Ramalan Sebaran Curah Hujan Periode Tertentu pada Wilayah yang Tidak Memiliki Data Curah Hujan. J Teknol Inf Din. 2012;17(2):154-63.

25. Ariati J, Anwar A. Prediction model event dengue hemorrhagic fever (dhf) based on climate factor in bogor, west java. Bul Penelit Kesehat. 2014;42(4):249-56.

26. Iriani $Y$. Hubungan antara Curah Hujan dan Peningkatan Kasus Demam Berdarah Dengue Anak di Kota Palembang. Sari Pediatr. 2012;13(6). 